University of Nebraska - Lincoln

DigitalCommons@University of Nebraska - Lincoln

USDA National Wildlife Research Center - Staff Publications
U.S. Department of Agriculture: Animal and Plant Health Inspection Service

January 2008

\title{
Evaluation of an electrified mat as a white-tailed deer (Odocoileus virginianus) barrier
}

Thomas W. Seamans

USDA/APHIS/WS National Wildlife Research Center, thomas.w.seamans@aphis.usda.gov

David A. Helon

United States Department of Agriculture/Animal Plant Health Inspection Service/Wildlife Services, National Wildlife Research Center

Follow this and additional works at: https://digitalcommons.unl.edu/icwdm_usdanwrc

Part of the Environmental Sciences Commons

Seamans, Thomas W. and Helon, David A., "Evaluation of an electrified mat as a white-tailed deer (Odocoileus virginianus) barrier" (2008). USDA National Wildlife Research Center - Staff Publications. 793. https://digitalcommons.unl.edu/icwdm_usdanwrc/793

This Article is brought to you for free and open access by the U.S. Department of Agriculture: Animal and Plant Health Inspection Service at DigitalCommons@University of Nebraska - Lincoln. It has been accepted for inclusion in USDA National Wildlife Research Center - Staff Publications by an authorized administrator of DigitalCommons@University of Nebraska - Lincoln. 


\title{
Evaluation of an electrified mat as a white-tailed deer (Odocoileus virginianus) barrier
}

\author{
THOMAS W. SEAMANS \& DAVID A. HELON
}

United States Department of Agriculture/Animal Plant Health Inspection Service/Wildlife Services, National Wildlife Research Center, Ohio Field Station, Sandusky, OH, USA

\begin{abstract}
White-tailed deer (Odocoileus virginianus) pose economic and safety problems for agricultural and transportation industries. We tested an electronic mat to determine if it would reduce deer crossing through fence openings. We measured deer intrusions and corn consumption at five sites with charged mats and five sites with non-charged mats. Weekly intrusions at treated sites decreased an average of $95 \%$ from pre-treatment. Weekly intrusions at control sites were reduced $60 \%$ during weeks 1 and 2 and increased to $10 \%$ reduction by week 6 . Weekly corn consumption at treated sites decreased from pretreatment through all treatment weeks. Weekly corn consumption at control sites decreased in weeks $1-4$ and 6 but was not different from pre-treatment in week 5. Consumption remained higher than expected at treated sites because deer jumped over or broke through the fence that delineated sites. Based upon the conditions and results of this test, we believe that electrified mats could reduce deer passage through fence openings.
\end{abstract}

Keywords: Deer, electric mat, Odocoileus virginianus, white-tailed deer, wildlife damage management

\section{Introduction}

White-tailed deer (Odocoileus virginianus) are abundant in the United States with a conservatively estimated population of 17 million individuals (McCabe and McCabe 1997). White-tailed deer have become a source of conflict due to their increased numbers and ability to live in proximity to humans (Conover et al. 1995). Deer pose direct hazards to people when they move in the way of vehicles, whether automobiles or aircraft (Bashore and Bellis 1982; Conover et al. 1995; Wright 1996; Wright et al. 1998; Dolbeer et al. 2000). Deer damage to agricultural and timber productivity in the United States may be $\$ 500$ million US and $\$ 750$ million US annually for agriculture and timber, respectively (Wywialowski 1994; Conover et al. 1995; Conover 1997). In 1993 the estimated costs of deer-automobile collisions in the United States were $\$ 1.1$ billion US with an estimated 29000 human injuries (Conover et al. 1995). Between 1990 and 2005, there were at least 652 civil aircraft collisions in the United States with white-tailed deer. Damage to aircraft occurred in $82 \%$ of these collisions with a total reported cost of $\$ 25.1$ million US. Seventeen strikes resulted in human injuries with one fatality (Cleary et al. 2006). Therefore, deer pose significant risks to public safety on roadways and airfields as well as causing serious economic loss for agricultural producers.
The most effective means of reducing the number of deer on an airport, road or crop-producing areas is to make it difficult for deer to gain access the grounds. Fences of various designs are effective at reducing deer intrusions (Brenneman 1983; McAninch et al. 1983; Palmer et al. 1983; Craven and Hygnstrom 1994; Seamans and VerCauteren 2006). However, openings in fences for vehicles provide access points for deer. A grid of metal bars or tubes over a shallow pit, commonly called cattle guards or cattle grids, provide a means of reducing intrusions (Belant et al. 1998a; Peterson et al. 2003) but may be too expensive for some individuals to install. Frightening devices at openings would not be effective for extended periods of time because deer habituate to the devices (Bomford and O'Brien 1990; Craven and Hygnstrom 1994; Curtis et al. 1995; Belant et al. 1998b,c; Beringer et al. 2003).

An effective, economical deer barrier at gates is needed to exclude deer from airfields, busy roadways and crop-producing areas. A potential barrier is an electrified mat that would function as an electric cattle guard. A deer stepping on the mat should receive an electric shock. The reaction of the deer could be to ignore the mat, bound forward and jump the mat or jump back and leave. We evaluated a prototype electronic mat, made from recycled plastic moulded into boards that was developed by ElectroBraid ${ }^{\mathrm{TM}}$ (Yarmouth, Nova Scotia, Canada) to determine its 
effectiveness in modifying the behaviour of whitetailed deer.

Mention of companies or commercial products does not imply recommendation or endorsement by the US Department of Agriculture over others not mentioned. The US Department of Agriculture neither guarantees nor warrants the standard of any product mentioned. Product names are mentioned solely to report factually on available data and to provide specific information. The National Wildlife Research Center Animal Care and Use Committee approved our procedures before the start of the study.

\section{Methods}

Research was conducted within the 2200-ha National Aeronautic Space Administration Plum Brook Station (PBS), Erie County, $\mathrm{OH}\left(41^{\circ} 27^{\prime} \mathrm{N}\right.$, $\left.82^{\circ} 42^{\prime} \mathrm{W}\right)$. A $2.4-\mathrm{m}$ high chain-link fence with barbed-wire outriggers enclosed the facility. Habitat within PBS differed from the surrounding agricultural and urban area and consisted of dogwood (Cornus spp.) (39\%), grass-forb fields (31\%), open woodlands $(15 \%)$, mixed hardwood forests $(11 \%)$, and roads and buildings (4\%) (Rose and Harder 1985). The estimated minimum deer density was $54 \mathrm{~km}^{-2}$ (J. D. Cepek, US Department of Agriculture, unpublished data), reflecting a high deer density when compared to common winter densities in the midwestern and Great Lakes regions of the United States of 6-13 deer $\mathrm{km}^{-2}$ (Gladfelter 1984; Menzel 1984).

We established 10 deer feeding sites $\geq 1 \mathrm{~km}$ apart during December 2004. At each station we erected a plastic snow fence $(1.8 \mathrm{~m}$ high) around three and a half sides of a $1.2-\mathrm{m}$ long feed trough so that the trough was about $3 \mathrm{~m}$ from the back of the opening of the $6.1 \times 6.1-\mathrm{m}$ enclosure (Figure 1). Each trough

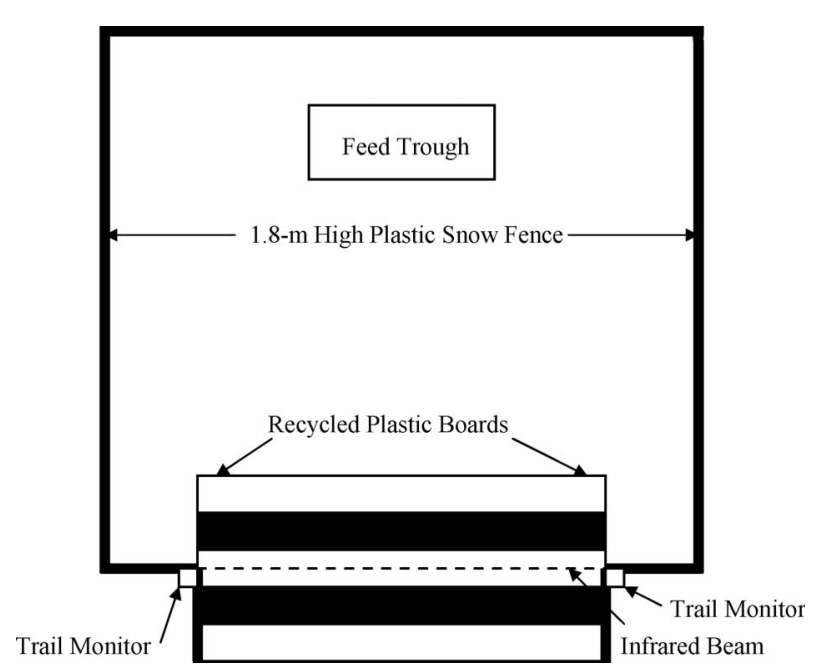

Figure 1 . Overhead view of a $6.1 \times 6.1-\mathrm{m}$ deer feed station used to test efficacy of a $3 \times 1.2-\mathrm{m}$ electrified mat as a deer deterrent during February to March 2005 in Erie County, OH. Five sites had electrified mats and five sites had no electricity. was supplied with dried, whole-kernel corn. Daily corn consumption was monitored by fitting each feed trough with a metal indicator plate at each end of the trough that had been calibrated for corn and inscribed at 4.5-kg intervals (Belant et al. 1997). We estimated corn consumption to the nearest $2.3 \mathrm{~kg}$ by interpolating the distance between the $4.5-\mathrm{kg}$ intervals. We added corn to feed troughs as necessary to maintain a constant food supply $(\approx 25 \mathrm{~kg})$. We did not attempt to differentiate between corn consumed by deer and that consumed by raccoons (Procyon lotor) or fox squirrels (Sciurus niger). We believed all sites were subject to comparable wildlife pressure (Blackwell et al. 2004). We used an active-infrared trail-monitoring device (TrailMaster ${ }^{\circledR}$, Goodson and Associates, Incorporated, Lenexa, KS) at the opening of the site to count deer visits to the trough. The device was installed $60 \mathrm{~cm}$ above ground at each opening to continually monitor the number of deer intrusions and avoid recording non-target species (e.g. raccoon, fox squirrel).

We monitored each site until all sites had $\geq 10 \mathrm{~kg}$ of corn consumption and $\geq 15$ intrusions daily for 7 days (pre-treatment period). We randomly selected five sites to receive a mat that would be electrified whereas the remaining five sites received a mat that was not electrified.

It took 4 days to install the mats at the 10 sites. Each mat was constructed out of five $24-\mathrm{cm}$ wide (including tongue-and-groove flange) $\times 4-\mathrm{cm}$ thick $\times 3$-m long recycled plastic boards (US Plastic Lumber, Chicago, IL) that were either yellow or black. As deer have the ability to discern some colours (VerCauteren and Pipas 2003) we believed that the contrasting yellow and black, which would serve as aposematic colours (Smith 1975; Caldwell and Rubinoff 1983; Blackwell 2002), might enhance the effect of the electrical shock. At all treated sites and three control sites we alternated yellow and black boards so that there were three yellow and two black boards. We did not have enough black boards to complete all sites, so at one control site we used one black board in the middle of the mat and four yellow boards. At the remaining control site we used only yellow boards. Three grooves, $6.5 \mathrm{~cm}$ apart, were cut into each board. Each groove, at treated sites, had a brass bar with a truncated triangular cross-section ( $2 \mathrm{~cm}$ at the base, $1 \mathrm{~cm}$ tall and $1 \mathrm{~cm}$ wide at the top) inserted into the groove so that the top of the brass bar was level with the top of the board (Figure 2). A flat brass strip was laid across all the brass bars so that all bars were electrified. The mat was powered by a Viper ${ }^{\text {TM }} 5000$ solar-powered energizer (Tru-Test Inc., San Antonio, TX) that had a maximum pulse output of 5 Joules and was powered by a $12-\mathrm{V}$ deepcycle battery.

After installation of the mats, we recorded daily corn consumption, deer intrusions, and voltage for 6 weeks from 3 February to 18 March 2005. Because 


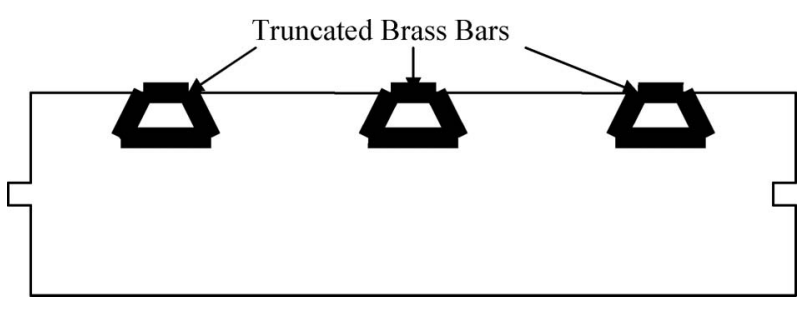

Figure 2. Cross-sectional view of a plastic board showing approximate placement of brass rods in board. Each board was $3 \mathrm{~m}$ long and $24 \mathrm{~cm}$ wide with brass rods $6.5 \mathrm{~cm}$ apart when measured from the closest exposed edge.

white-tailed deer home ranges can exceed $1 \mathrm{~km}$ (Marchinton and Hirth 1984), we did not consider treated and control sites as independent (i.e. the same deer could possibly feed at multiple sites within and between treatments). We also assumed that our sample size of feeding stations $(N=10)$ and the estimated number of deer present would produce substantial intrusions and corn consumption and approximate normality with regard to site-specific corn consumption per unit time. Due to the lack of independence between sites, assumptions for both parametric and non-parametric tests would be violated. We therefore compared use of one resource type (corn) between periods within a treatment (i.e. treated or controls) by use of $95 \%$ confidence limits (Haney and Solow 1992; Cherry 1996; Johnson 1999; Brown et al. 2000). We calculated binomial confidence limits about the proportion of total corn consumption and separately around intrusions that occurred during the pretreatment period $\left(p_{\mathrm{pt}}\right)$ as

$$
p_{\mathrm{pt}} ! z_{(1-\alpha / 2)}\left[p_{\mathrm{pt}}\left(1-p_{\mathrm{pt}}\right) / N\right]^{1 / 2}
$$

where $N$ is the total corn consumption or intrusions within a treatment and over the pre-treatment, and treatment periods. The confidence interval thus served as a basis for evaluating increase or decrease in corn consumption or intrusions in subsequent periods. If confidence coefficients did not include expected values, then observed and expected proportions differed significantly $\left(\alpha=0.05 Z_{(1-\alpha / 2)}=1.96\right)$. However, although we calculated separate intervals for pre-treatment corn consumption and intrusions at treatment and control sites (i.e. a within-treatment comparison), corn was present concurrently at all sites and, thus effects of the electric mat on corn consumption and intrusions at treated versus control sites can be inferred.

We noted but did not quantify damage to the snow fence (e.g. fence that was ripped, torn down or pulled away from fence posts) surrounding the sites. Fence damage was repaired daily. We had one Reconyx ${ }^{\mathrm{TM}}$ digital camera and moved it to each site throughout the study in an attempt to learn how deer were entering the sites. Weather conditions for the $24-\mathrm{h}$ period between checks were recorded.

\section{Results}

Mean ambient temperature during the test was $-4.2^{\circ} \mathrm{C}$ and ranged from -14 to $10.6^{\circ} \mathrm{C}$. Mean snow depth was $3.6 \mathrm{~cm}$ and ranged from 0 to $15.2 \mathrm{~cm}$. The mean percent snow cover was $45 \%$ and ranged from 0 to $100 \%$.

Prior to placing mats at each site, mean $( \pm S E)$ daily intrusions at treated sites $(66.9 \pm 7.1)$ was similar $(U=1.25, \quad P=0.21) \quad$ to control sites $(60.3 \pm 8.4)$. Daily mean corn consumption during this time at treated sites $(25.9 \pm 2)$ was greater $(U=2.18, \quad P=0.03) \quad$ than at control sites $(19.8 \pm 1.5)$.

Weekly intrusions across the mat at treated sites decreased an average of $95 \%$ from pre-treatment through all treatment weeks. Weekly intrusions across the mat at control sites were lower throughout the test when compared to pre-treatment. Intrusions decreased by $60 \%$ in weeks 1 and 2 compared to pre-treatment and gradually returned to $10 \%$ by week 6 .

Weekly corn consumption at treated sites decreased from pre-treatment through all treatment weeks. Consumption increased from week 1 ( $57 \%$ of pre-treatment amount) to week 6 (79\% of pretreatment). Weekly corn consumption at control sites also decreased from pre-treatment in weeks $1-$ 4 and 6 but was similar during week 5 . Consumption at control sites ranged from $55 \%$ of pretreatment in week 1 to $10 \%$ of pre-treatment in week 5 (Figure 3).

Snow fence at treated sites received some form of damage on 72 occasions while control site fences had damage on 65 occasions. Three treated sites had damage on 43,52 , and $69 \%$ of the checks and one control site had damage on $69 \%$ of the daily checks. Photographs indicated that deer damaged the fence by attempting to jump over the fence, by tearing a hole and going through the fence, or by pushing the fence down using their head, neck and feet.

Mean daily voltage was $5.9 \mathrm{kV}$. All sites dropped below $4 \mathrm{kV}$ at least four times with complete power loss on one occasion at three sites during daylight hours. We checked voltage at the mats at dawn on two occasions and found sites reading $0 \mathrm{kV}$ at dawn increasing to $2.5-3.4 \mathrm{kV}$ within $1 \mathrm{~h}$ after sunrise.

\section{Discussion}

The decrease in entries at control sites may be attributed to the foreign nature of the plastic boards at the entrance. Based on tracks at the sites and some of the photographs taken it was evident that when the control mat was first put down deer would begin to walk on the mat and then back away from it and jump over the snow fence. After the first 2 weeks deer began walking on the control mats but not the treated mats. Based on the camera photographs we believe 

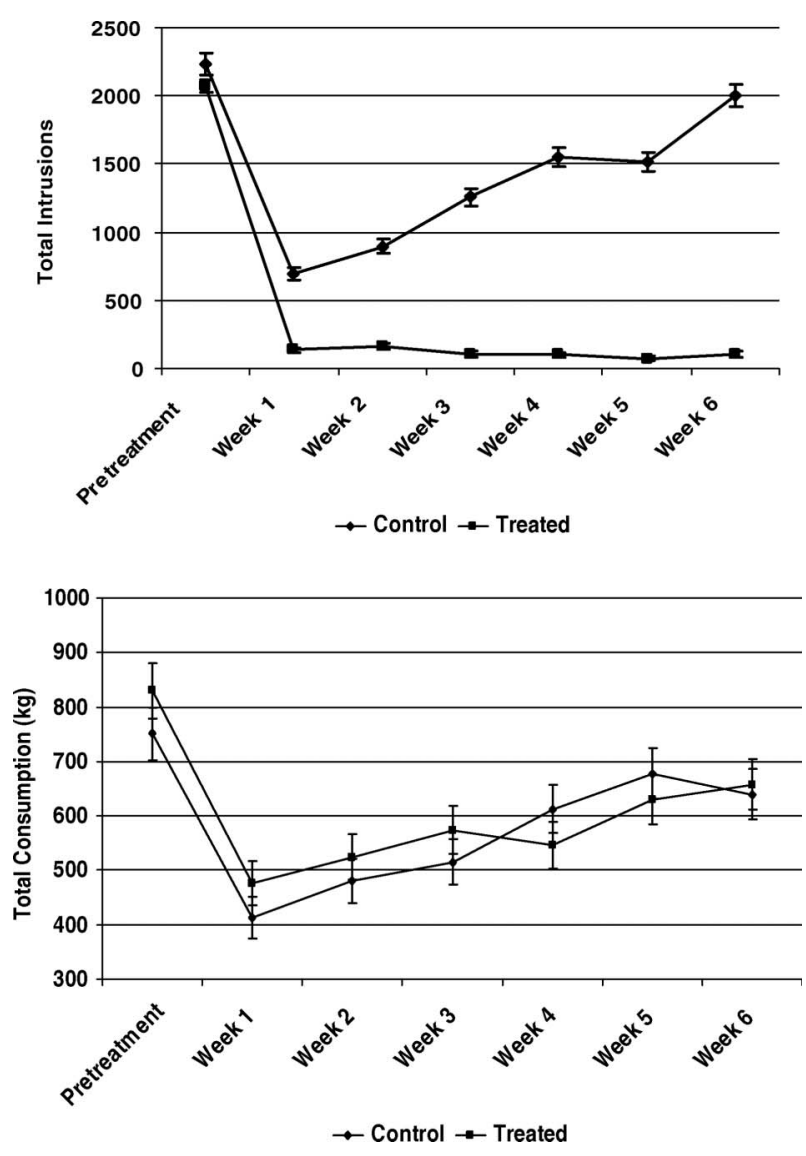

Figure 3. Total weekly ( $95 \%$ confidence intervals indicated by error bars) deer intrusions (top) and corn consumption (kg; bottom) at 10 sites with a mat of recycled plastic boards placed at the entrance, February to March 2005, Erie County, OH. Treated site mats were electrified and control sites were not.

that deer were not moving between treated and control sites. Therefore, the lack of intrusions across control mats was not likely due to deer received a shock at treated sites and attributing that pain to control mats but was due to the physical nature of the plastic boards. When deer crossed treated mats it was during the night, especially from midnight to the predawn hour. It was at this time that we consider the battery to have been discharged and the mat either not powered at all or power reduced to the point that the shock was minimal. This problem can be resolved by adjusting the power system. This does indicate that deer could sense the electrical activity and knew when to avoid treated mats.

Deer continued to feed at all sites as evidenced by corn consumption and tracks in the snow. The reduced amount of feed consumed may in part be due to fewer deer entering the site because of the plastic boards (at control sites), getting shocked, or because of the inconvenience of getting over or through the fence. This change in comfort level associated with each site might also have reduced feed consumption. Deer changed their method of entry into sites by jumping over or tearing through the 1.8-m high plastic snow fence surrounding each site. This change in behaviour continued at treated sites for the entire 6 weeks of the study but generally stopped occurring at control sites after the initial 2 weeks of the test. In previous studies, covering 10 years of work, using this same design but different control devices, deer seldom jumped or damaged the snow fence but continued to enter through the fence opening to the site (Belant et al. 1998b,c; Seamans and VerCauteren 2006). In a test with coyote (Canis latrans) hair used as an area repellent, deer did not circumvent the snow fence nor enter through the front opening (Seamans et al. 2002).

Although deer could easily have jumped across the mat, they generally did not do so. We do not know why they did not jump but speculate that it was because they had been shocked at some point and chose to stay away from the source of the pain. Similar avoidance behaviour was observed when white-tailed deer were kept from a food source by an electric fence that they could have easily jumped but did not (Seamans and VerCauteren 2006).

We do not know how long it would take a deer to either learn to jump over the mat or be willing to tolerate some pain in order to gain the benefit of the food. In tests with an electric fence we noted some individual deer learned to pass through the fence in a manner that kept the shock to a minimum (Seamans and VerCauteren 2006). It might thus be possible for deer to learn to circumvent the deterrent effect of the electric mat. However, in cases where the area being protected was well defined (i.e. airports, orchards), deer that learned to 'defeat' the mat could be killed under proper permits. Thus, the chance of other deer learning to defeat the mat by following these initial deer would be reduced. Based on the results from this test and the electric fence test (Seamans and VerCauteren 2006), we anticipate that the number of deer that would learn to get by the mat would be small.

People can receive a shock from this prototype electric mat. If a person is earthed/grounded and touches one of the electrified metal bars then a shock will be received. If someone is positioned entirely on the electric mat then no shock will be felt. The mat, as tested, contained no more electric force than an electric fence, therefore although the shock could be felt it was not dangerous. However, if someone had a heart condition any shock could be harmful (Fowler and Miles 2002). As with an electric fence, signs should be posted to alert people to the potential hazard presented by the mat.

Standard cattle grids cost about $\$ 1000$ US for a $3.6 \times 1.8-\mathrm{m}$ guard (American Fence and Supply Co., Georgetown, TX). Material costs for the $3 \times 1.2-\mathrm{m}$ mats used in this test were about $\$ 550$ US. However, standard cattle guards require minimal maintenance while the electric mat would require more maintenance to maintain the electric charge and to keep it clear of snow and ice so that an animal would receive a shock. Additionally, there would be a variable cost for electricity to maintain the 
repellence of the mat. Unlike standard cattle guards which provide a rough surface to drive over, the mats used in our test could be installed flush with the road and provide a smooth surface for a vehicle to cross. Before the mat could be used where large, commercial aircraft or trucks would cross over it the mat would have to undergo testing to determine if it would withstand the vehicle's weight.

Belant et al. (1998a) found that $4.6 \times 3-\mathrm{m}$ simulated cattle grids reduced deer crossings by $95 \%$. There was some evidence that deer attempted to jump the simulated grids and landed in the middle of the grid. Assuming that the report accurately reflects deer usage of cattle grids then the similar decrease in deer crossings in this test and the lack of evidence of deer jumping the mat would tend to indicate that the electronic mat could be as effective at reducing deer crossings through fence openings as cattle grids.

We believe that the test regime used provided a gauge of the efficacy of the electrified mat. The test occurred in an area with high deer densities $\left(54 \mathrm{~km}^{-2}\right)$ during an energetically stressful period with a desirable food source (Wywialowski 1996) as an attractant. The fact that deer entered the site by jumping over the snow fence is notable because this is a change in behaviour from previous tests and white-tailed deer generally crawl under or through obstacles when they are not disturbed (Sauer 1984). Based on deer behaviour, the combination of plastic boards and a painful stimulus created a fence opening that deer preferred to avoid. This tool, used in conjunction with fencing, harassment, habitat management, and lethal control (Cleary and Dolbeer 2005) can provides an opportunity to reduce the number of deer present in areas that are potentially dangerous for deer and in areas where deer are a threat to human safety.

\section{Acknowledgments}

We thank ElectroBraid Fence Limited for supplying electrical equipment and $\mathrm{J}$. Bearse and $\mathrm{R}$. Lampman for assistance in setting up mats. We thank R. C. Beason, B. F. Blackwell, and B. E. Washburn for field assistance. We thank R. Puzak, NASA Plum Brook Station for access to study sites.

\section{References}

Bashore TL, Bellis ED. 1982. Deer on Pennsylvania airfields: problems and means of control. Wildlife Society Bulletin 10:386-388.

Belant JL, Ickes SK, Tyson LA, Seamans TW. 1997. Comparison of four particulate substances as wildlife feeding repellents. Crop Protection 16:439-447.

Belant JL, Seamans TW, Dwyer CP. 1998a. Cattle guards reduce white-tailed deer crossings through fence openings. International Journal of Pest Management 44:247-249.

Belant JL, Seamans TW, Tyson LA. 1998b. Evaluation of electronic frightening devices as white-tailed deer deterrents. Vertebrate Pest Conference 18:107-110.
Belant JL, Seamans TW, Tyson LA. 1998c. Predator urines as chemical barriers to white-tailed deer. Vertebrate Pest Conference 18:359-362.

Beringer J, VerCauteren KC, Millspaugh JJ. 2003. Evaluation of an animal-activated scarecrow and a monofilament fence for reducing deer use of soybean fields. Wildlife Society Bulletin 31:492-498.

Blackwell BF. 2002. Understanding avian vision: the key to using light in bird management. Vertebrate Pest Conference 20:146152.

Blackwell BF, Seamans TW, White RJ, Patton ZJ, Bush RM, Cepek JD. 2004. Exposure time of oral rabies vaccine baits relative to baiting density and raccoon population density. Journal of Wildlife Diseases 40:222-229.

Bomford M, O'Brien PH. 1990. Sonic deterrents in animal damage control: a review of device tests and effectiveness. Wildlife Society Bulletin 18:411-422.

Brenneman R. 1983. Use of electric fencing to prevent deer browsing in Allegheny hardwood forests. Eastern Wildlife Damage Control Conference 1:97-98.

Brown WK, Hall WK, Linton LR, Huenefeld RE, Shipley LA. 2000. Repellency of three compounds to caribou. Wildlife Society Bulletin 28:365-371.

Caldwell GS, Rubinoff RW. 1983. Avoidance of venomous sea snakes by naïve herons and egrets. Auk 100:195-198.

Cherry S. 1996. A comparison of confidence interval methods for habitat use-availability studies. Journal of Wildlife Management 60:653-658.

Cleary EC, Dolbeer RA. 2005. Wildlife hazard management at airports, a manual for airport personnel. 2nd ed. US Department of Transportation, Federal Aviation Administration, Office of Airport Safety and Standards. FAA, Office of Airport Safety and Standards: Washington, DC, USA, p 348.

Cleary EC, Wright SE, Dolbeer RA. 2006. Wildlife strikes to civilian aircraft in the United States, 1990-2005. Federal Aviation Administration, Wildlife Aircraft Strike Database Serial Report 12.

Conover MR. 1997. Monetary and intangible valuation of deer in the United States. Wildlife Society Bulletin 25:298-305.

Conover MR, Pitt WC, Kessler KK, DuBow TJ, Sanborn WA. 1995. Review of human injuries, illnesses, and economic losses caused by wildlife in the United States. Wildlife Society Bulletin 23:407-414.

Craven SR, Hyngstrom SE. 1994. Deer. In: Hyngstrom SE, Timm RM, Larson GE, editors. Prevention and control of wildlife damage. University of Nebraska Cooperative Extension Service, Lincoln, Nebraska, USA. pp D25-D40.

Curtis PD, Fitzgerald C, Richmond ME. 1995. Evaluation of the Yard Gard ultrasonic yard protector for repelling white-tailed deer. Eastern Wildlife Damage Control Conference 7:172-176.

Dolbeer RA, Wright SE, Cleary EC. 2000. Ranking the hazard level of wildlife species to aviation. Wildlife Society Bulletin 28:372-378.

Fowler TW, Miles KK. 2002. Electrical safety: safety and health for electrical trades-student manual. Department of Health and Human Services, Centers for Disease Control and Prevention, National Institute for Occupational Safety and Health Publication No. 2002-123. (NIOSH: Cincinnati.)

Gladfelter HL. 1984. Midwest agricultural region. In: Halls LK, editor. White-tailed deer ecology and management. Harrisburg, PA: Stackpole Books. pp 427-440.

Haney JC, Solow AR. 1992. Testing for resource use and selection by marine birds. Journal of Field Ornithology 63:43-52.

Johnson DH. 1999. The insignificance of statistical significance testing. Journal of Wildlife Management 63:763-772.

Marchinton RL, Hirth DH. 1984. Behavior. In: Halls LK, editor. White-tailed deer ecology and management, Harrisburg, PA: Stackpole Books. pp 129-168.

McAninch JB, Winchombe R, Ellingwood M. 1983. Fence designs for deer control: a review and the results of recent research in southeastern New York. Eastern Wildlife Damage Control Conference 1:101. 
McCabe TR, McCabe RE. 1997. Recounting whitetails past. In: McShea WJ, Underwood HB, Rappole JH, editors. The science of overabundance: deer ecology and population management. Washington, DC: Smithsonian Institution. pp 11-26.

Menzel KE. 1984. Central and southern plains. In: Halls LK, editor. White-tailed deer ecology and management. Harrisburg, PA: Stackpole Books. pp 449-456.

Palmer WL, Wingard RG, George JL. 1983. Deer damage control in Pennsylvania agriculture. Eastern Wildlife Damage Control Conference 1:75-76.

Peterson MN, Lopez RR, Silvy NJ, Owen CB, Frank PA, Braden AW. 2003. Evaluation of deer-exclusion grates in urban areas. Wildlife Society Bulletin 31:1198-1204.

Rose J, Harder JD. 1985. Seasonal feeding habits of an enclosed high density white-tailed deer herd in northern Ohio. Ohio Journal of Science 85:184-190.

Sauer P. 1984. Physical characteristics. In: Halls LK, editor. White-tailed deer ecology and management. Harrisburg, PA: Stackpole Books. pp 73-90.
Seamans TW, VerCauteren KC. 2006. Evaluation of ElectroBraid $^{\mathrm{TM}}$ fencing as a white-tailed deer barrier. Wildlife Society Bulletin 34:8-15.

Seamans TW, Blackwell BF, Cepek JD. 2002. Coyote hair as an area repellent for white-tailed deer. International Journal of Pest Management 48:301-306.

Smith SM. 1975. Innate recognition of coral snake pattern by a possible avian predator. Science 187:759-760.

VerCauteren KC, Pipas MJ. 2003. A review of color vision in white-tailed deer. Wildlife Society Bulletin 31:684-691.

Wright S. 1996. Watch out for Rudolph! FAA Aviation News 35:19-23.

Wright SE, Dolbeer RA, Montoney AJ. 1998. Deer on airports: an accident waiting to happen. Vertebrate Pest Conference 18: 90-95.

Wywialowski AP. 1994. Agricultural producers' perceptions of wildlife-caused losses. Wildlife Society Bulletin 22:370-382.

Wywialowski AP. 1996. Wildlife damage to field corn in 1993. Wildlife Society Bulletin 24:264-271. 